\section{REFERENCES}

rrows, W. B. 1912. Michigan Bird Life (quoted by A. C. Bent, 1929).

tes, J. M. 1907. The Bartramian Sandpiper. Bird-lore, $9: 84$

ck, H. H. 1949. Status of the upland plover in Lancaster County, Pennsylvania. Auk, 66 (2) :202-204.

ent, A. C. 1929. Life histories of North American shore birds. U.S. Nat. Mus. Bull. 146.

iss, Irven, O. 1951. The upland plover in southwestern Yukon Territory. Arctic, 4 (3) : 204-213.

iss, Irven, O. and A. S. Hawkins. 1939. The upland plover at Faville Grove, Wisconsin. Wilson Bulletin, 51(4): 202-220.

ues, Elliot. 1874. Birds of the North-West (quoted by A. C. Bent, 1929).

orbush, E. H. 1912. A history of game birds, wild fowl, and shore birds of Massachusetts and adjacent states (quoted by A. C. Bent. 1929).

udson, W. H. 1920. Birds of La Plata (quoted by A. C. Bent, 1929).

udson, W. H. 1922. A hind in Richmond

Park (quoted by A. C. Bent, 1929).
McAtee, W. L. and F. E. L. Beal. 1912. Some common game, aquatic and rapacious birds in relation to man. U.S. Dept. of Agric., Farmer's Bull. 497 (quoted by A. C. Bent, 1929).

Mure, Adolph. 1946. Observations on the birds of Mount McKinley National Park, Alaska. The Condor, 48(6): 253-261.

Roberts, T. S. 1919. Water birds of Minnesota past and present. Biennial Rep. of the State Game and Fish Comm. of Minn., for the Biennial Period ending July 31, 1918 (quoted by A. C. Bent, 1929).

Rowan, William. 1926. Notes on Alberta waders included in the British list. Brit. $h$ Birds, $20: 2-10,34-42,82-90,138-145,186-192$ (quoted by A. C. Bent, 1929).

Stevenson, J. O. 1942. Birds of the central panhandle of Texas. The Condor, 44(3):108115.

Terrill, L. McI. 1951. Shorebird migration at Montreal. Can. Field Nat., 65(3):87-98.

Urner, C. A. and R. W. Storer. 1949. The distribution and abundance of shorebirds on the north and central New Jersey coast, 19281938. Auk, 66 (2):177-194.

Wetmore, Alexander. 1926. Observations on the birds of Argentina, Paraguay, Uruguay, and Chile. U.S. Nat. Mus. Bull. 133 (quoted by A. C. Bent, 1929).

\title{
NOTES ON THE BREEDING BIOLOGY OF THE MARSH HAWK IN ALBERTA AND SASKATCHEWAN
}

\section{by Spencer G. Sealy, Department of Zoology, U.B.C., Vancouver}

This study of the breeding biology $f$ the Marsh Hawk, Circus cyaneus Linnaeus), was carried out in Alerta and Saskatchewan during the ummers of 1959 to 1964. Four sumhers were spent in the Battleford rea of northwest central Saskatchetan and two in the Brooks area of outheastern Alberta. The Battleford rea $\left(52^{\prime} \mathrm{N}, 108^{\prime} \mathrm{W}\right)$ is situated in he forest and grassland portion of he Boreal Forest Region (Rowe, 959); the Brooks area $\left(50^{\prime} \mathrm{N}, 111^{\prime}\right.$ V) is situated in the Grassland Reion (Rowe, op. cit.). The two areas re roughly 250 miles apart (see igure 1). A total of 32 nests was tudied and a discussion of nest-buildng, eggs, egg-laying and incubation, and young and their development is resented.

The Battleford area consists of unlulating, grass - covered hills interpersed with groves of aspen (Populus remuloides) on a level above the
North Saskatchewan and Battle rivers, the northern boundary of the area under consideration. Approximately 35 percent of the area was under cultivation at the time of this study, the remaining portion being tree-covered or pastureland. Aspen stands grow in small to large groves at intermittent spots on hillsides and in valleys; in other locations along the North Saskatchewan and Battle rivers balsam poplar ( $P$. balsamifera), white birch (Betula papyrifera), willow (Salix spp.), saskatoon (Amelanchier) and hawthorne (Crataegus) are also prevalent species. No natural coniferous growth is present although a few planted stands serve as shelterbelts on some farms. Patches of rose (Rosa) and snowberry (Symphoricarpus), locally known as "buckbrush", are numerous between the tree groves.

The Brooks area, which is situated in the Eastern Irrigation District 


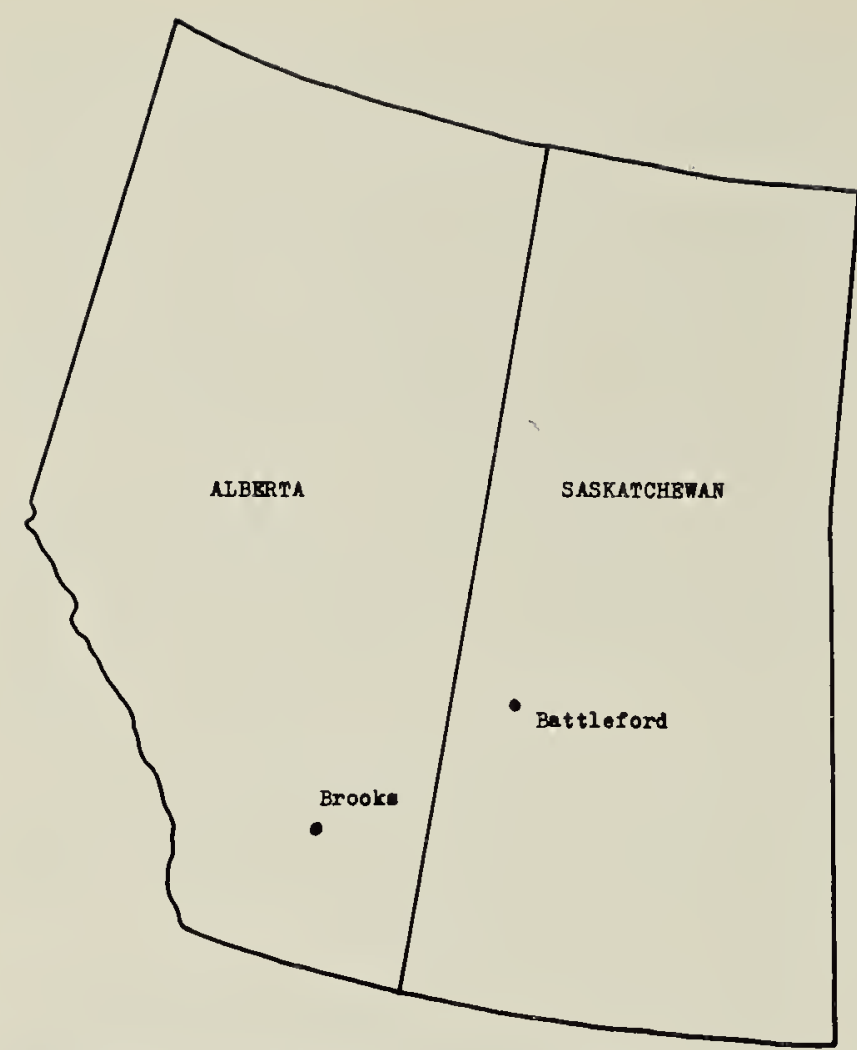

Figure 1. Map showing the location of the Marsh Hawk study areas.

where the annual precipitation is normally too low for the production of cereal crops, has been transformed into arable land by irrigation. Many marshes have developed here in connection with artificial lakes and backwaters. Predominant marsh plants are cattails (Typha) and bulrush (Scirpus). Bordering many of the irrigation canals and marshes are willow and poplar. A Stipa-Bouteloua grass association is found in those parts of the area not touched by irrigation (Moss, 1959).

\section{Nest and Nest-building}

The Marsh Hawk builds a simple nest, usually placed directly on the ground, though sometimes over water. I have no data on nest-site selection or the initial construction of the nest; Pettingill (1956) proposes that the need of suitable support and protection governs the selection of the nest site. The nests I studied were in positions of this nature.

Van Tyne and Berger (1961) distinguish six ways in which the labour involved in nest construction by birds may be divided between the male and female. In my study, only the female Marsh Hawk was observed to construct the nest; however, both adults were observed carrying nest-material to the nest site, the male hovering over the female at the nest site and dropping the material to her. Nesting materials were added throughout the nesting season. An adult female was observed at 7:00 a.m. on July 7, 1964, carrying nesting material (grass) to her nest in the cattails near Brooks. At this date the nest contained one young approximately three weeks old and three unhatched eggs.

In my study I found nests placed in several kinds of plant cover, and this seemed to have some influence on nest success.

In the Battleford area 21 nests were on the ground in clumps of snowberry and rose. Seven nests were measured; these nests averaged $50.0 \mathrm{~mm} \quad(1.97$ in) in depth (much shallower than those situated above water in a marsh) with an average outside diameter of $390 \mathrm{~mm}$ (16.18 in) and inside diameter of $250 \mathrm{~mm}$ (9.84 in). As the nestlings grew they gradually trampled the nest against the ground. At about three weeks of age the nestlings began to move out and hide in the surrounding vegetation.

TABLE 1. Summary of clutch sizes, hatching success and fledging success of Marsh Hawk nests studied from 1959 to 1962 in the Battleford area, Saskatchewan.

\begin{tabular}{lccccc}
\hline Year & $\begin{array}{c}\text { No. eggs } \\
\text { in clutches }\end{array}$ & $\begin{array}{c}\text { No. eggs } \\
\text { hatched }\end{array}$ & $\begin{array}{c}\text { Per cent } \\
\text { hatching } \\
\text { success }\end{array}$ & $\begin{array}{c}\text { Per cent } \\
\text { fledging } \\
\text { success }\end{array}$ & $\begin{array}{c}\text { Mean } \\
\text { clutch } \\
\text { size }\end{array}$ \\
\hline 1959 & $26(5)^{*}$ & 19 & 73.07 & 68.42 & 5.30 \\
1960 & $24(7)$ & 19 & 79.16 & 100.00 & 3.42 \\
1961 & $18(5)$ & 16 & 88.89 & 100.00 & 3.60 \\
1962 & $17(4)$ & 4 & 23.46 & 00.00 & 4.45 \\
\hline Totals & $85(21)$ & 58 & $\bar{x}=62.35$ & $\bar{x}=67.11$ & $\overline{\bar{x}}=4.18$ \\
\hline
\end{tabular}

* The number of clutches studied. 
Total percent fledging success in Battleford area was high in 1959 , 80 and 1961 (see table 1) in the owberry habitat. In 1962, of four sts in snowberry-rose habitat, none is successful in producing any ung, each nest being destroyed by known factors.

In the Brooks area nine out of 11 sts were in cattail marsh and the st was constructed in the form of a atform. Five nests were measured, th an average depth of $240 \mathrm{~mm}$ .45 in.), an average outside diaeter of $630 \mathrm{~mm}$ ( $24.80 \mathrm{in})$ and inside ameter of $255 \mathrm{~mm}$ (10.03 in). A nest this type is a bulky but durable cucture with its great depth proding security against potential inease in the water level. The nest is loyant, floating on the water surface ce a raft. As the nestlings grew the st became soggy and water-logged it supported them.

In the Brooks area nine nests in ttails had a much better fledgling ccess than two found in wheatgrass 1gropyron) cover (see table 2). The tter two nests showed a hatching ccess comparable to other situations d other years but failed to produce hy young which reached the flying age. The young simply disappeared, hich would indicate a high degree of redation once the eggs had hatched. hose nests placed in cattails, hower, showed a similar percent hatch$\mathrm{g}$ success but also a very high total rcent fledging rate $(100 \%$ in five at of seven nests observed in catils). These nests, being out in a arsh over water, are less accessible most of the potential mammalian edators in this area; for example, pe coyote (Canis latrans), striped kunk (Mephitis mephitis) and bader (Taxidea taxus). Predation by

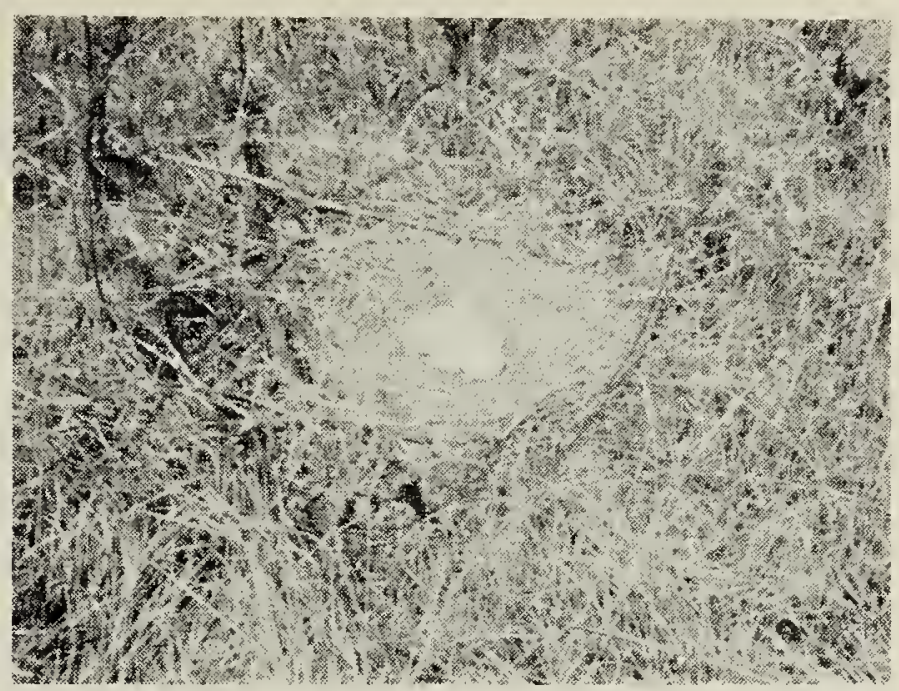

Figure 2. Nest and eggs of the Marsh Hawk on the ground in wheatgrass, Brooks, June 3, 1964.

gulls (Larus spp.) was not observed at nests in the cattails but was abserved on one occasion (June 19, 1964) at a nest situated in wheatgrass cover.

Three nests situated in cattails in the Brooks area were analyzed for their percentage floral composition. In one nest the Russian thistle (Salsola) comprised $85 \%$ of the floral components, the remaining $15 \%$ being Aster $(10 \%)$, Typha (3\%) and Stipa (2\%). The second nest was constructed with Russian thistle, cattail, aster and lined with aspen, wheat (Triticum) and speargrass. The third nest was composed of Russian thistle and aster lined with pasture sage (Artemisia frigida).

One nest situated in Agropyron cover in the Brooks area (see Fig. 2) was also analyzed. Wheat comprised $98 \%$ of the total floral composition with Russian thistle and speargrass making up the remaining $2 \%$.

Many avian predators use the same nest year after year, the Ferruginous Hawk (Buteo regalis) and the Roughlegged Hawk (B. lagopus) being good

ABLE 2. Summary of percent fledging success of nests situated in Typha cover nd Agropyron cover in the Brooks area, 1963 and 1964.

\begin{tabular}{|llcll}
\hline & $\begin{array}{c}\text { Total No. } \\
\text { eggs laid }\end{array}$ & $\begin{array}{c}\text { Total No. } \\
\text { hatched }\end{array}$ & $\begin{array}{c}\text { Average } \\
\text { hatching } \\
\text { success }\end{array}$ & $\begin{array}{c}\text { Average } \\
\text { per cent } \\
\text { fledging } \\
\text { success }\end{array}$ \\
\hline Mpha cover & $29(9)^{*}$ & 18 & 62.07 & 83.33 \\
dgropyron cover & $11(2)$ & 7 & 63.63 & 00.00 \\
\hline
\end{tabular}

Number of nests in the sample. 
examples. In each case the nest is lined and added to each year until it becomes a large size, sometimes, in the case of the Rough-legged Hawk, having as many as 10 layers (Hanson, Queneau, and Scott, 1956). Marsh Hawks do not use the same nest over again; however, whether they use the same nesting site or clump of plant cover again I cannot say. I have found their nests in the same clump of snowberry in the Battleford area for four consecutive years, but as the adults were not colour-marked 0 banded it was impossible to be sure they were the same birds. Again in the Brooks area a nest was located in the same small marsh for two con secutive years (but in different parts of the marsh), and once again it was impossible to say whether they were the same birds. In England, Richmond (1959) states that "once a pair of Hen Harriers (Circus cyaneus) have established a territory, they return to the same area year after year, often

TABLE 3. Summary of clutch sizes, hatching success and fledging success of Marsh Hawk nests studied in 1963 and 1964 in the Brooks area, Alberta.

\begin{tabular}{lccccr}
\hline Year & $\begin{array}{c}\text { No. eggs } \\
\text { in clutches }\end{array}$ & $\begin{array}{c}\text { No. eggs } \\
\text { hatched }\end{array}$ & $\begin{array}{c}\text { Per cent } \\
\text { hatching } \\
\text { success }\end{array}$ & $\begin{array}{c}\text { Per cent } \\
\text { fledging } \\
\text { success }\end{array}$ & $\begin{array}{r}\text { Mean } \\
\text { clutch } \\
\text { size }\end{array}$ \\
\hline 1963 & $12(3)^{*}$ & 5 & 41.66 & 100.00 & 4.00 \\
1964 & $37(8)$ & 23 & 60.27 & 69.57 & 4.62 \\
\hline Totals & $49(11)$ & 28 & $\bar{x}=57.14$ & $\bar{x}=75.00$ & $\overline{\bar{x}}=4.45$
\end{tabular}

* The number of clutches studied.

TABLE 4. Incubation periods of the Marsh Hawk, Brooks, Alberta, 1964.

\begin{tabular}{ccccc}
\hline Nest No. & Egg No. & Date laid & Date hatched & $\begin{array}{c}\text { Incubation } \\
\text { Period }\end{array}$ \\
\hline 1 & 4 & May 28 & June 27 & 31 days \\
& 5 & May 30 & Did not & $\ldots \ldots \ldots \ldots \ldots$ \\
hatch & June 18 & 31 days \\
2 & 6 & May 19 & June 24 & 41 days \\
3 & 4 & May 15 &
\end{tabular}

Average incubation period $=34.3$ days.

TABLE 5. Hatching rhythm of Marsh Hawk chicks in three nests in the Brooks area, 1964.

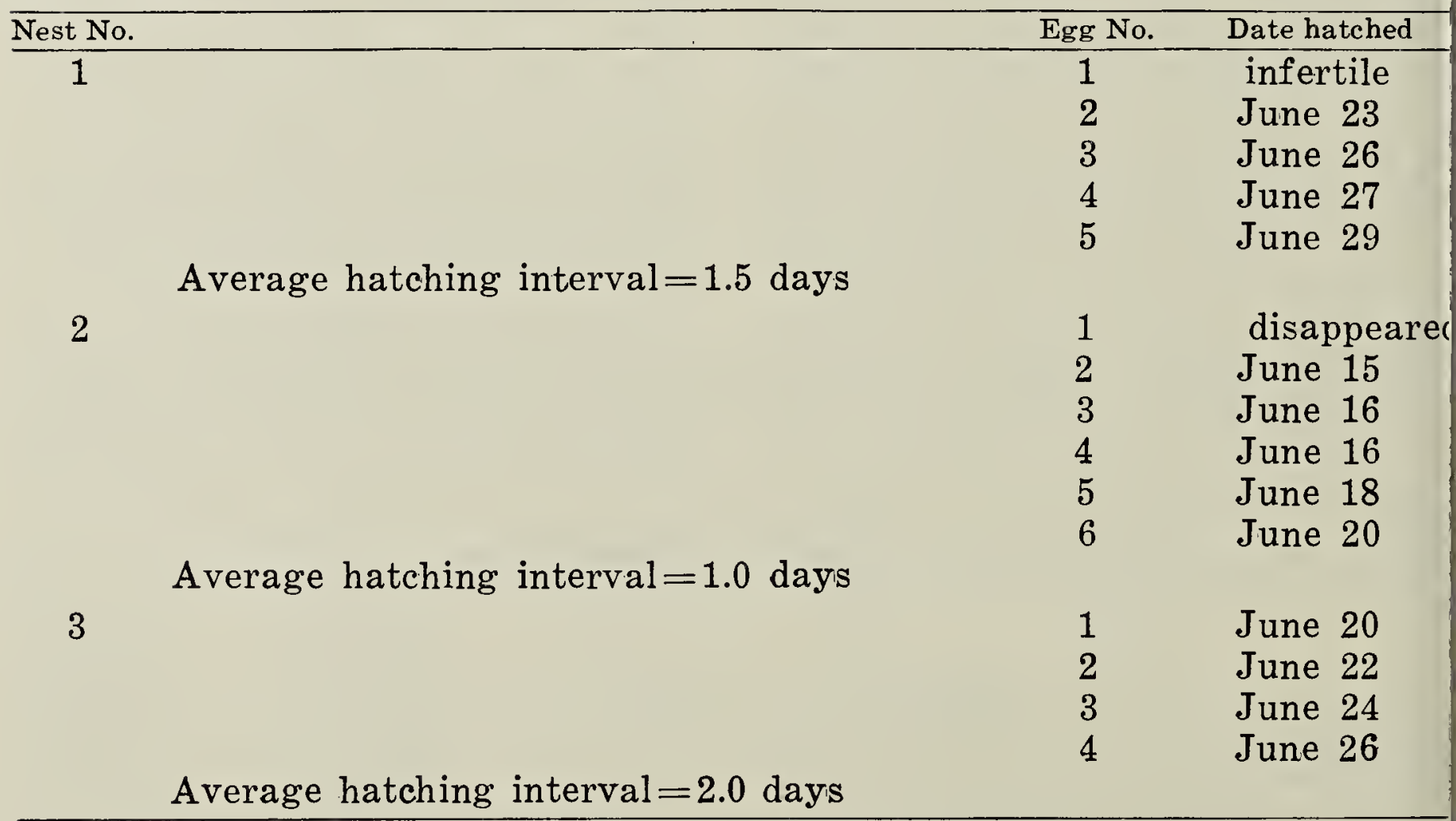


within a few yards of the spot here the original nest was built." It as not stated whether this observaon was based on the return of lour-marked birds.

\section{Eggs, Egg-laying and Incubation}

The Marsh Hawk lays bluish-white gs which are occasionally spotted ith brown over their entire surface. leasurements of $16 \mathrm{eggs}$ from the rooks area averaged $45.6 \times 36.2 \mathrm{~mm}$ $1.79 \times 1.42$ in) with extremes of 44.5 $47.0 \mathrm{~mm}$ ( 1.75 to $1.84 \mathrm{in}$ ) in length

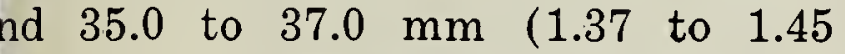
1) in width. Bent (1961) gives the verage of 84 Marsh Hawk eggs as $6.6 \times 36.4 \mathrm{~mm}$.

From tables 1 and 3 it may be seen hat the average clutch size of 21 ests studied at Battleford from 1959 1962 was 4.18 eggs with extreme lutch sizes of three to six eggs. Of ine nests studied at Brooks in 1963 nd 1964 the average clutch was 4.45 ggs with extremes of four to six ggs. Hammond and Henry (1949) reorted an average of 5.05 eggs per est in North Dakota. Maximum lutch sizes of nine eggs (Bent, 1961; 'earson, 1936) and ten eggs (Baumras, 1942) have been recorded.

Egg-laying began prior to compleion of the nest and after the first ne or two eggs were laid the female ontinued to construct and line the est. Upon deposition of the last egg he nest was generally completed. ach egg was laid during the early norning hours at an interval of two lays (in five clutches). Incubation, egun prior to completion of the lutch, was shared by both parents,

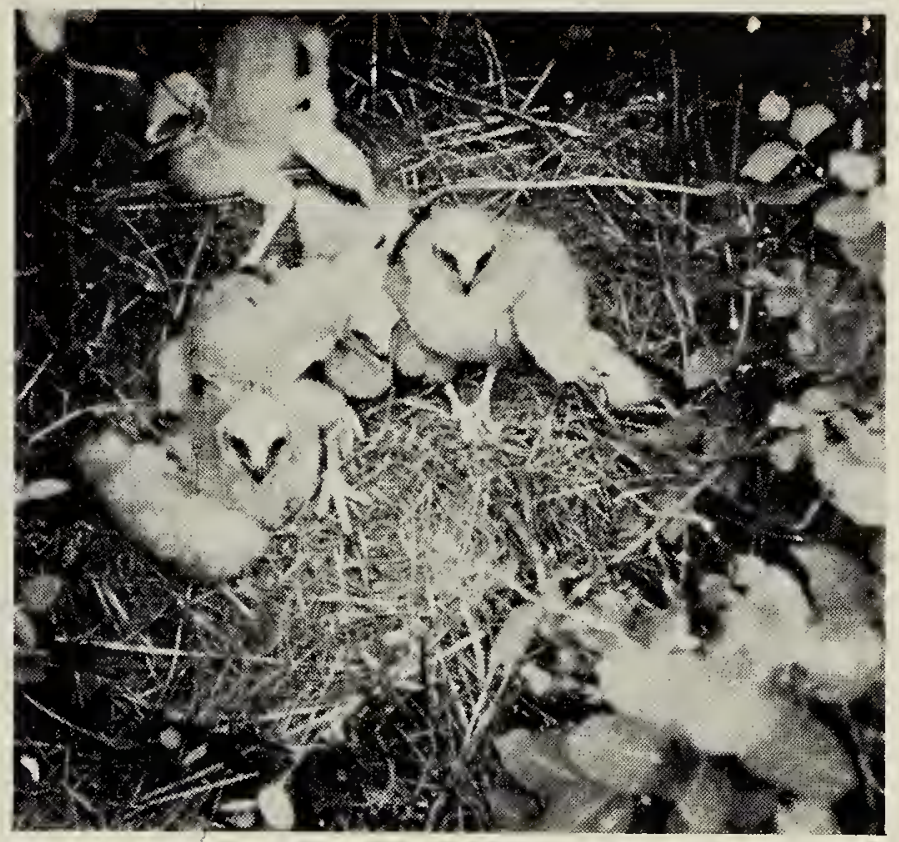

Figure 3. Fourteen-day-old Marsh Hawks, Battleford, June 28, 1960.

the female participating to a greater extent. Both parents defended the territory against intruders during the pre-egg-laying, egg-laying and nestling stages, with the degree of participation varying from one nest to another. The incubation period (calculated using the laying and hatching dates of the last egg in the clutch) was found to be 34.3 days (see table 4).

\section{Young and Their Development}

Since incubation commenced prior to laying of the entire clutch the eggs in each clutch did not hatch simultaneously. Table 5 shows the hatching rhythm of three nests in the Brooks area, 1964, with an overall hatching interval between each egg in a clutch being 1.59 days. The average length of time required for each egg to hatch

TABLE 6. Yearly hatching peaks for the Marsh Hawk in the Battleford and and Brooks study areas.

\begin{tabular}{lcc}
\hline Area & Year & Mean hatching date \\
\hline Battleford & 1959 & June 17 \\
Battleford & 1960 & June 15 \\
Battleford & 1961 & June 18 \\
Battleford & 1962 & June 21 \\
Overall mean hatching date $=$ June 17 & & \\
Brooks & 1963 & June 13 \\
Brooks & 1964 & June 18 \\
& &
\end{tabular}




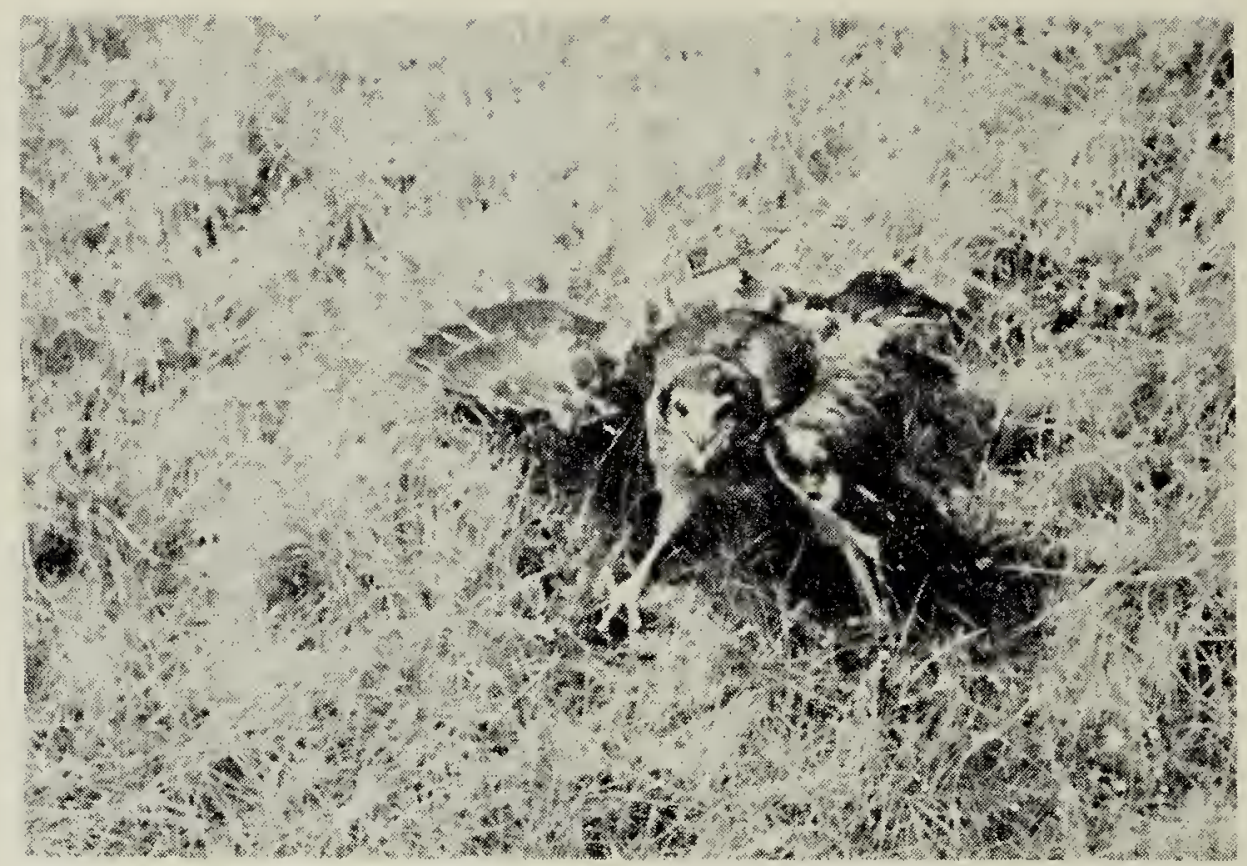

Figure 4. Thirty-five-day-old Marsh Hawk, Battleford, July 11, 1960.

(from the time it pipped to the emergence of the chick) was about 24 hours. The chick's egg-tooth was sloughed off at about five days of age (11 chicks observed).

Table 6 shows the hatching peaks for the Marsh Hawk for four years in the Battleford area and two years in the Brooks area. The overall hatching peak (calculated by averaging the hatching peaks of each clutch) was June 17 and June 15, respectively.

Young Marsh Hawks are altricial, that is, they are incapable of locomotion and entirely dependent upon the parents for food. They remained in the nest for about 35 days (see table 7), all the while being fed by the parents. At the time of hatching they are covered with whitish down tipped with buff on their dorsal and ventral surfaces. Their fleshy tarsi are whitish-yellow and their irises are brown at hatching, the former becoming yellowish-orange prior to fledging and the latter remaining the same.
Activity of the nestlings durin their early period of growth (unt about 10 days of age) is restricte to simple reflexes relating to grasp ing the floor of the nest with thei feet, to keeping their bodies uprigh and to feeding. A high-pitched "cheek cheek-cheek" is uttered by the nest lings at this stage. They began to us their feet as a means of defense a about 14 days of age, turning over of to their backs and clawing at an in truder. It was at this time that th young began to tear up some of thei food which previously had been tor up by the parents. At about 21 day of age many chicks scattered aroun the nest site and hid in the surround ing vegetation. Figures 3 and 4 shor young Marsh Hawks at about 14 day and 35 days of age, respectively.

Figure 5 presents the growth of 1 Marsh Hawk chicks from the time 0 hatching to fledging and table 8 show the growth using weight and lengt: of the tarsus and wing chord. Sinc

TABLE 7. Time spent in the nest by young Marsh Hawks in the Brooks area 1964.

\begin{tabular}{cccc}
\hline Nest No. & $\begin{array}{c}\text { Date hatched } \\
\text { (average of entire brood) }\end{array}$ & $\begin{array}{c}\text { Date left } \\
\text { nest }\end{array}$ & $\begin{array}{c}\text { Age } \\
\text { (in days) }\end{array}$ \\
\hline 3 & June 22 & July 27 & 35 \\
4 & June 13 & July 16 & 35 \\
5 & June 20 & July 23 & 35 \\
8 & June 12 & July 15 & 34 \\
\hline
\end{tabular}

Average age of chicks at time of departure $=34.7$ days 
ABLE 8. Growth of the Marsh Hawk in the Brooks area, 1964. Measurements f both sexes are treated together.

\begin{tabular}{|ccccc}
\hline $\begin{array}{c}\text { Age in } \\
\text { days }\end{array}$ & $\begin{array}{c}\text { No. in } \\
\text { sample }\end{array}$ & $\begin{array}{c}\text { Mean weight } \\
\text { in gm }\end{array}$ & $\begin{array}{c}\text { Mean tarsus } \\
\text { length in mm }\end{array}$ & $\begin{array}{c}\text { Mean wing chord length } \\
\text { in mm }\end{array}$ \\
\hline 3 & 14 & 74.5 & $32.0(1.26)^{*}$ & $31.7(1.25)^{*}$ \\
13 & 14 & 296.2 & $67.3(2.65)$ & $120.0(4.72)$ \\
15 & 14 & 356.2 & $73.3(2.89)$ & $143.6(5.65)$ \\
20 & 14 & 418.7 & $82.2(3.24)$ & $195.6(7.70)$ \\
22 & 14 & 445.0 & $83.3(3.28)$ & $213.0(8.39)$ \\
24 & 14 & 487.5 & $84.0(3.31)$ & $229.6(9.04)$ \\
27 & 14 & 506.2 & $84.8(3.34)$ & $253.3(9.97)$ \\
29 & 14 & 481.2 & $85.0(3.35)$ & $269.3(10.60)$ \\
33 & 1 & 375.0 & $80.0(3.15)$ & $268.0(10.55)$ \\
\hline
\end{tabular}

Corresponding measurements in inches given in parentheses.

issection was not carried out to valiate identification of sex based on xternal morphology, both sexes are reated together although the females re the larger in most raptor species. lthough the sample is small (Figure ) it may be noted that a slight drop n weight occurred prior to fledging. The activity of the young of many pecies of birds increases prior to ledging resulting in an increased nergy consumption and consequently

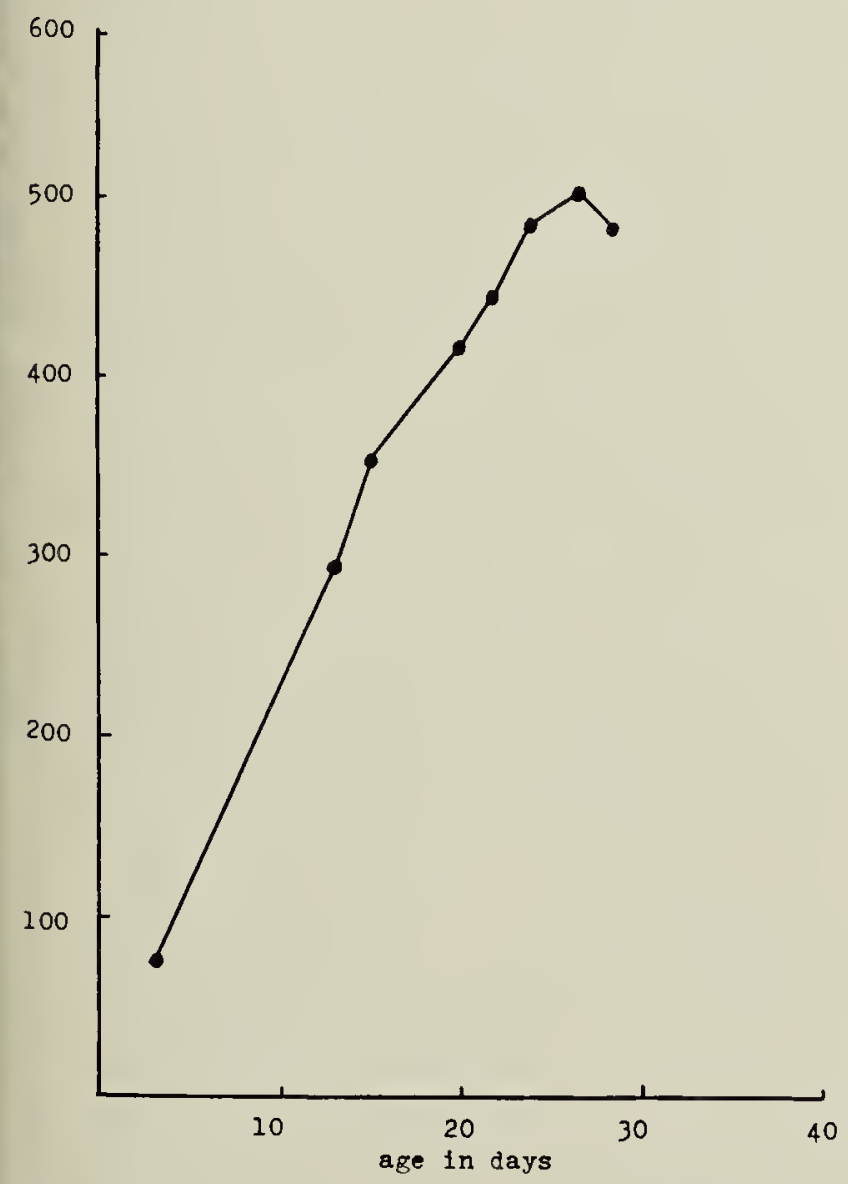

Figure 5. Growth in the Marsh Hawk at Brooks, Alberta, 1964. a drop in weight. This may be the case with the Marsh Hawk.

\section{Acknowledgements}

I should like to thank Dr. C. S. Houston for making it possible to band young Marsh Hawks at Battleford in 1960 and 1961 and also Harold Fisher and G. A. Fox for aiding in banding operations. In the Brooks area, Mr. C. A. Gordon and Mr. J. A. Wolford assisted in many phases of the work. Mr. S. Smoliak identified many of the plants and offered much general botanical information on the two study areas. Finally, I should like to thank Dr. M. D. F. Udvardy and Dr. R. W. Nero for helping me with drafts of the manuscript.

\section{LITERATURE CITED}

Baumgras, P. S. 1942. An unusual clutch of Marsh Hawk eggs. (Wils. Bull., $54: 50$.

Bent, A. C. 1937 (Dover reprint 1961). Life histories of North American birds of prey. Part 1. U.S. Natl. Mus., Wash., Dover Publications, Inc. New York.

Hammond, M.C., and C. J. Henry. 1949. Success of Marsh Hawk nests in North Dakota. Auk, $66: 271-274$.

Hanson, H. C., P. Queneau, and P. Scott. 1956. The geography, birds and mammals of the Perry River region. Arct. Instit. of $\mathrm{N}$. Am. Spec. Publ. No. 3.

Moss, E. H. 1959. Flora of Alberta. Univ. of Toronto Press.

Pearson, T. G. 1936. Birds of America. Doubleday and Co., Inc.

Pettingill, O. S. 1956. A laboratory and field manual of ornithology. 3rd edition. Burgess Publ. Co., Minneapolis.

Richmond, K. W. 1959. British birds of prey. Lutterworth Press.

Rowe, J. S. 1959. Forest regions of Canada. Canada Dept. of Northern Affairs and National Resources, Forestry Branch, Bull. 123.

Van Tyne, J., and A. J. Berger. 1961. Fundamentals of ornithology. John Wiley and Sons, Inc., New York. 